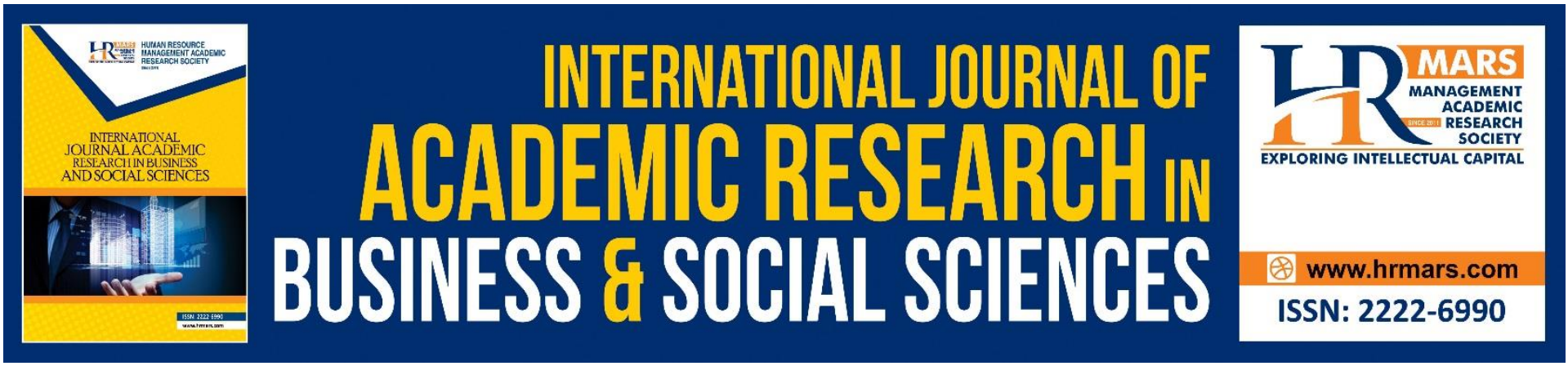

\title{
Determinants of Indicators for Risk Management Process of Royal Malaysian Customs Department
}

Norfadzilah Rashid, Nadiah Abd Hamid, Ab Halim Assar, Rohaya Md Noor, Zarinah Abdul Rasit, Salmah Jaafar, Ahmad Shukri Yazid

To Link this Article: http://dx.doi.org/10.6007/IJARBSS/v8-i12/5213

DOI: $10.6007 /$ IJARBSS/v8-i12/5213

Received: 03 Nov 2018, Revised: 13 Dec 2018, Accepted: 21 Dec 2018

Published Online: 29 Dec 2018

In-Text Citation: (Rashid et al., 2018)

To Cite this Article: Rashid, N., Hamid, N. A., Assar, A. H., Noor, R. M., Rasit, Z. A., Jaafar, S., \& Yazid, A. S. (2018). Determinants of Indicators for Risk Management Process of Royal Malaysian Customs Department. International Journal of Academic Research in Business and Social Sciences, 8(12), 1278-1300.

Copyright: (C) 2018 The Author(s)

Published by Human Resource Management Academic Research Society (www.hrmars.com) This article is published under the Creative Commons Attribution (CC BY 4.0) license. Anyone may reproduce, distribute, translate and create derivative works of this article (for both commercial and non-commercial purposes), subject to full attribution to the original publication and authors. The full terms of this license may be seen at: http://creativecommons.org/licences/by/4.0/legalcode

Vol. 8, No. 12, 2018, Pg. 1278 - 1300

http://hrmars.com/index.php/pages/detail/IJARBSS

JOURNAL HOMEPAGE

Full Terms \& Conditions of access and use can be found at http://hrmars.com/index.php/pages/detail/publication-ethics 


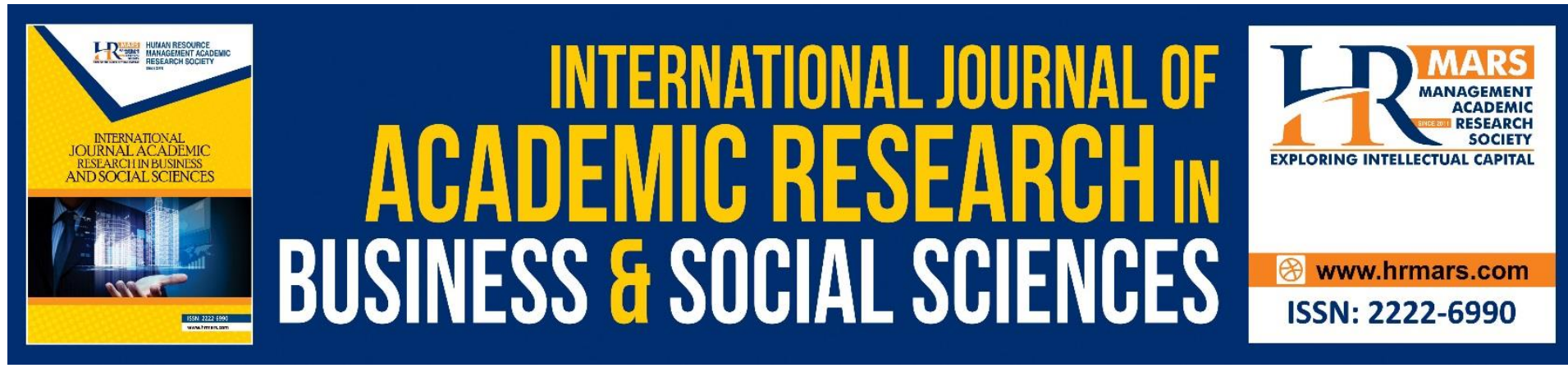

\title{
Determinants of Indicators for Risk Management Process of Royal Malaysian Customs Department
}

\author{
${ }^{1}$ Norfadzilah Rashid, ${ }^{2}$ Nadiah Abd Hamid, ${ }^{3} \mathrm{Ab}$ Halim Assar, \\ ${ }^{4}$ Rohaya Md Noor, ${ }^{5}$ Zarinah Abdul Rasit, ${ }^{6}$ Salmah Jaafar, \\ ${ }^{7}$ Ahmad Shukri Yazid \\ 2,3,4,5,6 Faculty of Accountancy, Universiti Teknologi MARA, 42300 Bandar Puncak Alam, \\ Malaysia \\ ${ }^{1,7}$ Faculty Economic \& Management Science,Universiti Sultan Zainal Abidin, Terengganu, \\ Malaysia
}

\begin{abstract}
Tax evasion and tax avoidance have become the central issue in the revenue collection in Malaysia. Although, the higher penalty was imposed to the tax evader, the tax gap detected during auditing process seems crucial. Thus, it is timely for Royal Malaysian Customs Department (RMCD) to improve its risk management systems in order to reduce tax evasion particularly with the current implementation of Goods and Services Tax (GST) on 1st April 2015. This study was conducted to examine the factors of auditor's profile that influence audit performance. The sample data of this study cover tax collection from resolved audit cases conducted by RMCD based on the audit findings for the year 2012 to 2014 . The findings reveal that there was a significant relationship between size of company, tax rate and penalty towards audit performance. Hence, the findings of the study may contribute in terms of strategic information to the government by revealing the significance of profiling data of tax evaders in the industry during the tax audit selection. The audit recovery from the Risk Management System can be improved to encourage and promoting a better audit detection process.
\end{abstract}

Keywords: Evasion, Royal Malaysian Customs,tax gap, risk management, revenue, and Goods and Services Tax.

\section{Introduction}

Taxation has become the current economic agenda in providing a stable flow of revenue to finance public expenditure particularly for vital services such as national security, maintaining law and order, healthcare, education and training and to strengthen its physical infrastructure (Vladu \& Matis 2010). On the other hand, the malfunction of taxation exists when the tax distorts consumers' behavior by discouraging consumption through the imposition of higher taxes and duties, particularly, on goods such as tobacco and liquor or gaming activities (Alm \& Torgler 2011).

Similar to other nations, tax revenue in Malaysia comes from two sources, the direct and indirect taxes. The two government agencies responsible in collecting the taxes are the Inland 
Revenue Board of Malaysia (IRBM) that handles the collection of direct taxes while, the Royal Malaysian Customs Department (RMCD) is responsible for the collection of the indirect taxes. In 2013, about RM120.5 billion of direct taxes and RM35.4 billion of indirect taxes were collected by IRBM and RMCD respectively (Miskam et al. 2013). The huge gap in the amount of tax collected by RMCD as compared to IRBM has led RMCD to strengthen its administration by avoiding leakages in revenue collection while simultaneously, curbing illegitimate borders' activities and tightening controls in deterring frauds. Furthermore, the issue of tax evasion has become the central issue in the revenue collection in Malaysia both for direct and indirect tax. As defined by (Nicolaes et al. 2015) tax evasion is the deliberate failure of disclosing the full or partial income to the tax authority, and it causes pervasive effect on economic growth and income redistribution. Even though, the higher penalty was imposed on the tax evaders, the increasing tax gap detected during the auditing process seemed alarming.

The risk management techniques are found to be useful waysof ensuring enforcement, security and trade facilitation. Two analysis had been used in applying the risk management techniques, namely, risk analysis and risk assessment. Both these techniques are used to identify serious threat from risks and to give priority for corrective action. Through risk management techniques, preferences are concentrated on risky profiles of businesses or persons that are considered to impose higher risks while, consignments and persons that are classified as "low risk" are based on the fact that their risk profiles attracted minimal attention and intervention from the customs (Ying et al. 2017). From previous studies, researchers have concentrated more towards examining the factor related to tax evasion using the compliance model (Kenyon 2008). Only few studies investigated the operation of risk management techniques especially related to Customs organization (Hashimzade et al. 2010). The goal of this study is to determine the risk profiles of businesses and auditors' entities that influence the audit selection process. Specifically, this study aims to investigate the indicators for risk management system based on the previous audit case selection during SST. This study is timely given that the implementation of GST needs to be carefully monitored to ensure full compliance of the system. In addition, these findings are vital to support RMCD transformation programs towards achieving its target of speedy audit and zero fraud cases.

\section{Problem Background}

For the past sixty (60) years, the volume of international trade has increased exponentially. Most of the business activities have crossed beyond boundaries, and many strategic cooperation were signed between Malaysia and foreign countries. From various trading community perspectives, international trade has become increasingly challenging and complex. (Schweinberger 2012) stating that total trade in September 2014 was valued at RM119.7 billion which increased by $1.6 \%$ compared to 2013 . This increase was contributed mainly by higher trade with Singapore (increased RM2.21 billion), Taiwan (increased RM1.64 billion), Australia (increased RM1.06 billion), the Netherlands (up from RM854.7 million), Hong Kong (increased RM391.6 million) and New Zealand (up from RM366.3 million).

Customs had limitation of resources that can be mobilized to handle increasing trade, and their reinforcement has not caught up with the stride of international trade growth (Daniela \& Attila 2013). The volume of business improvements on regional trade agreements and trade preferential treatment policies make the responsibility of Royal Malaysian Customs Department (RMCD) increasingly harder and tougher. Globalization of international trade has provided an opportunity for companies and individuals around the world to trade with each other. According to (Aerts \& Zhang 2014) the expansion of international trade and pressure 
from the international trading community have changed the role of Customs as gatekeeper at the borders to facilitate trade. To ensure the regulatory control and commerce facilitation, many Customs Department worldwide have adopted the risk management strategy, which was outlined in the WCO's Revised Kyoto Convention (Noor et al. 2011). The most prominent risks face by any Customs office are non-compliant or illegitimate commercial transactions that reduce government's revenue and distribute dangerous goods that will threaten the society (Bouraoui et al. 2014).

In 2013, RM648 millions of indirect taxes comprising import duties, excise duties and sales tax were detected to be under-declared during RMCD audits. In addition, from RMCD Annual Report, RMCD Company Audit Branch had detected tax deficiency amounting to RM104.95 million, RM103.02 million and RM250.51 million respectively for the three consecutive years from 2012 to 2014. The numbers of audit turnover showing a decreased from 2,949 cases in 2012 to 2,597 cases in 2014. Tax gap is defined as the difference between the amount of tax declared by the business or importers and the actual of tax paid to RMCD. Through auditing, all the transactions made together with the supporting documents for at least three years were examined and verified. It is from auditing, it was found that businesses usually evade the indirect taxes by under declaring the value of goods or sales and in the case of imports, a declassification of the products or its tariff code are done to attract lower duties and to fabricate false invoices.

Even though higher penalties are imposed on tax evaders, the tax gap detected during auditing is alarming. Hence, it is crucial for RMCD to improve its risk management systems to reduce the tax evasion. Through detailed examination on the available information of the non-compliance cases obtained from RMCD's audit activities, a set of risk profiles can be developed and used as fraud risk indicators in the selection of audit sampling.

There are many factors contributing to the complexity, such as; the volume of transactions, the type of industry, type of tax, tax rate, and lack of computerised accounting system used, demographic factors and the human resources capabilities. As for this research, the audit department is selected due to its critical role in detecting tax evasion which usually involve tax not declared, tax underpaid whether due to valuation or misclassification of commodities and noncompliance.

Tax evasion has become more sophisticated, complicated and advanced, where the nature of fraudulent has gone through much evolution over time. Furthermore, the majority of international trade involves huge corporations with many global networks and complex business information systems and supply chains. However, in some cases, trade documentation that is required to be produced at the point of import does not give a clear description of the consignment and the context of a commercial transaction. The required trade documentation is essential to determine correctly, among other things, the correct custom's value, classification or entitlement of the preferential origin.

As a result of the development in international trading, audit in RMCD has evolved too and a more efficient consumption tax such as the Goods and Services Tax Act 2014 is needed. The increasing complexity of business transaction and rapid changes in information technology, especially in computerized accounting system have led RMCD to comprehend all aspect of its customer's business environment. Also, the use of the latest technology as audit tools help auditors to deal with complex and complicated transactions.

The collected information on fraud risk indicators can assist RMCD in assessing the business risk profiles systematically and further can be translated to be specific criteria. The model will suggest the efficient way to predict the probability of businesses evading tax. 
Furthermore, these measures will minimise the undue bias in howthe audit cases aredistributed to the tax auditors by developing specific indicators to facilitate the auditing procedure.

\section{LITERATURE REVIEW}

Tax evasion has become a threat to the tax system as it reduces the effectiveness of collecting the tax revenue. There are many ways of evading taxes either direct or indirect taxes. In the case of direct taxes, individuals can evade taxes using many schemes such as under-reporting earnings, overstating deductions and failing to file appropriate tax returns. Similarly, the same method can be used to evade indirect taxes such as import duty, excise duty, sales or service tax. They can evade the custom duty by using fake invoice, under declaring the quantity, undervaluing the price or using the lower import tariff at the point of declaration. Furthermore, the increasing globalization of economic activities provide more opportunities for both individual and firm to commit tax evasion through border shopping, transfer pricing and smuggling (Richardson et al. 2013).

Among the traditional approaches to measure tax evasion is through the individual tax returns. (Rashid et al. 2015) measured the indirect tax evasion namely service tax and excise duties by using the data from particular audited cases conducted by RMCD. However, the most difficult part of doing research in tax evasion is to get the real findings which represent the right behavior of individuals, but the reality is that no one would reveal their actual behavior of tax evasion (Amirah et al. 2017). However, only few researches focused on the risk indicators of tax evasion especially in the case of smuggling and transfer pricing as it involves international trade. For examples, (Miskam et al. 2013) used indicators such as type of auditor and company size, while, (Noor et al. 2008) explored on import tax duty and commodities differentiation as the indicators for detecting non-compliance cases for indirect taxes.

Under risk management techniques, two analyses had been used to enhance customs control and customs clearance process. These analyses are risk analysis and risk assessment which are used to identify and select auditee with the highest risk for non-compliance cases and provide the possible corrective action. In selecting the non-compliance cases, risk fraud profile is used which include many indicators such as type of industry, company profile and previous compliance records of traders, commodities valuation, place of business, transport mode and offended passengers (Braun \& Rodriguez, Jr. 2014). These indicators are important to assist in auditing the highly risk profiles. In conducting audit selection for fraud risk assessment profiles, it involves the process of evaluating non-compliance cases from its past history (Rashid et al. 2014a). The process will involve data within the business organization itself or any related data from other agencies.

\section{Probability of Audit Detection Process}

The percentage of tax audit executed compared to the tax returns received by the tax authority are quite small in most countries. It is almost always less than one percent of all returns (Rashid et al. 2016). Higher audit probabilities of detection will encourage tax compliance and reduce tax evasion. The probability of detection can be defined as the possibility that RMCD will discover any fraudulent or noncompliance and able to remedy the factors leading to evasion activities. Businesses will evade their tax obligation entirely, and the motivation was that there is probability not to be caught (Benmelech \& Dvir 2013). By strengthening the audit method on the probability of detection will directly reduce tax 
evasion and this is an effective detection measure usually practice by tax authority's auditor (Richardson et al. 2013). Furthermore, audits are considered to have the direct preventive effect on audited businesses and indirect deterrent influence on companies that are not being audited. In a study by (Baber et al. 2014) they found the significant positive relationship between the risk probability of tax audit and the rate of evasion. However, the study by (Toolson 2014) indicated that audit related only an uncertain positive effect on tax compliance.

Measurement of the probability of audit detection effectiveness will be based on the number of audit cases completed and the total collection derived from the audit findings. The RMCD has established the key performance indicator (KPI) for every auditor to complete 48 cases in a year. For the division total annual collection, RMCD Compliance Division has set the projection to collect short tax payment from tax audit for the amount of RM300 million (Afthanorhan et al. 2019).

Most businesses are worried about the possibility of their actions being detected because any illegal activities traced by RMCD will make them liable for legal action. (Cerqueti \& Coppier 2011) stated that there are two categories of tax evasion that occur. The first category comprised factors that are negatively affecting taxpayers' compliance with the tax legislation that is a low willingness to pay taxes (low tax morale), while the second category involved the limited ability of tax administration and fiscal courts to enforce tax liabilities, as well as insufficiencies in the administration and collection of taxes (weak monitoring).

(Hana et al. 2014) stated that the Internal Revenue Service (IRS) has defined and measured the gap in tax context is the difference between the amount of actual tax obligation compared to the non-payment or underpaid. The tax gap could be attributed to three sources. The first scenario is when the taxpayer is underreporting their income, overstating deductions, overstating business expenses, erroneously claim credits, and this contribute to about 80 percent of the gap. The second situation is the occurrence of non-filing offences, where this involved a taxpayer who is required to file a return, but fail to do so. In the third situation is in the event of underpayment that occurs when taxpayers file returns but fail to remit the amount due. Furthermore, there are three different aspects of tax evasion which are underreporting of taxable quantities, underreporting of the unit value and the miscoding of higher-taxed products to be lower-taxed (Hashimzade et al. 2010).

\section{Penalty Rate}

According to the model of tax evasion pioneered by (Saad 2014) it is shown that the prediction model was concerned with the effects of the increase in the penalty rate and the positive shift in the probability of detection continued to hold. The higher penalty rate and a higher likelihood of being detected may act as a deterrent to tax evasion. (Vijayakumar \& Karunaiathal 2014) cited that the probability function must be considered to reflect the taxpayers' belief regarding the policy to be followed by the tax collection agency. Based on Sandmo's A-S model, it was assumed that the probability of detection might increase the amount of tax evaded but this would depend on how the taxpayers viewed such a possibility. The taxpayers' probability of audit detection would likely increase due to the amount of tax evaded. However, when the probability of audit detection decreased, they may decide to evade more tax.

(Danielova \& Sarkar 2011) determined the factors on the effectiveness of the tax system structure of any country that included the probability of detection, penalty, tax rate and the complexity of the tax system. Through the tax audit process and investigation, 
noncompliant acts by the taxpayers may be detected. The purpose of the tax audit in the RMCD is to identify the taxpayers who has not complied with the submission of tax forms and the payment of tax. Also, (AbRahman et al. 2016) stated that the tax audits not only had a direct deterrent effect on the taxpayers being audited but also had an indirect deterrent effect on the taxpayers not being audited.

Another important factor that affected probability of audit detection is the relationship between tax evasion and the severity of punishments to offences committed by taxpayers. The impression is that the fear of consequences from offences will prohibit the evasion behavior. Establishing an effective probability detection system to detect tax evaders and penalize them is becoming necessary measures in audit tasks. Businesses will be more compliance if the fraudulent act may result in severe penalties. According to (Rashid, Hamid, Bentong, et al. 2017) in their theoretical work, tax evasion can be reduced by increasing offences penalties associated with the act. In order to make audit more effective, penalties need to be applied speedily and effectively by force. Research done by (Russo 2013) indicated that respondents admitting that some form of tax evasion were less likely to be perpetrated if the acts would lead to severe penalties.

For deterrence theory, penalties were included as one of the three elements that may discourage the intention to evade taxes (Cummings et al. 2009). (Wang 2013) generated a model that assumed penalties were assessed on the level of income taxes evaded. They also reported that the substitution effect in the Allingham-Sandmo (A-S) model occurs that the penalty rate remained fixed even when the regular tax rate increased but on the other hand, the difference between the penalty rate and the regular tax rate when decreased, it would increase the incentive to underreport the income.

Looking at the study by (Nik Mohd Norfadzilah Nik Mohd Rashid, Hamid, Taib, et al. 2017) which formulated a model of tax evasion under the allowance for retroactive penalties, it was suggested that retroactive penalties would increase the deterrence of evasion.

\section{Level of Threshold}

The level of the threshold may affect tax evasion and increase the probability of being detected by the audit. Tax is charged depending on two major elements: the nature of the business and the annual revenue (not profit) of the threshold. The tax is imposed to be charged from no threshold to RM3,000,000 ranges for annual revenue. There are limits of threshold with the taxable goods and services in terms of licensing and GST registration as well. Previously under SST, any person or company is required to be licensed when they run a business of providing taxable goods and services and achieved certain limits of the threshold.

Some of the studies concentrated on same principle issues of threshold in the GST comparable system, which is the Value Added Tax (VAT) system. The key characteristics of VAT are the level of the threshold based on the turnover of the companies, and they became obliged to register with tax authorities (Overesch \& Wamser 2014). They also found that the existence of threshold created two important impacts on tax revenue and firm's behaviour. According to (Moyes et al. 2013) if the threshold is set too high by tax authorities, it would affect in the decrease of tax revenue and the number of the burdened tax companies. Also, (Yazid et al. 2017) extended the previous research by (Litt et al. 2013) regarding the impact of the threshold on the firm's tax evasion behavior. (Amirah et al. 2017) found out that when the threshold was higher, the number of businesses below the threshold would increase, and companies above the threshold were likely to opt for tax evasion. However, if the threshold 
were too low, small firms would be tempted to evade the tax due to high compliance costs. So, the level of threshold could be influenced by the firm's behaviour of tax evasion.

In the case of RMCD, the different levels of threshold in designing the source of revenue for the government are seen to be a critical point. In order to reduce the financial burden, the government might be losing tax revenue by raising the threshold. This was seen in 2008 where the threshold of restaurants outside of hotel premises was increased from RM500,000 to RM3 million. During that year, the government had to bear a lost in tax revenue of about RM182 million. However, this loss was also a net cost to government which could be translated into savings which could be passed to the customers by way of lower prices.

In the 2008 Budget, the Malaysian government announced the abolishment of professional services threshold such as accountancy, legal firms, management and consultancy effective from 1 January 2008. According to the Minister of Finance, the abolishment would help the professional service to compete with each other among the same provider in a beneficial way. The impact of abolishing the threshold would help to reduce the risk of being penalized for the failure to obtain the license and failure to collect service tax which resulted in compliance cost saving.

\section{Size of Company}

Dellaportas (2013) reported that large firms endured higher political costs compared to the smaller firms, and as a result, large firms were less likely to evade their tax responsibilities, using the ratio of income tax to the operating income as his effective tax rate measure. Therefore, he suggested an inverse relationship between effective tax rates and firm size using the ratio of current income tax to the pre-tax book income and extraordinary items as his effective tax rate measure (Rashid, Muhmad, Chehaat, et al. 2017). In Hong Kong, a strong negative relationship was found between effective tax rates and firm size by using political cost (Rashid, Noor, Mastuki, et al. 2017). Otherwise, the relationship was found not significant in Malaysia and Taiwan.

Ali \& Torgler (2011) studied the relationship between corporate non-compliance and organizational characteristics where they found that the bigger firms with more complicated operations had greater tendency not to complied with the tax law. (Noor et al. 2011) discovered that size of companies by total sales had a significant adverse effect on tax evasion activities. These findings were consistent with (Poel \& Vanstraelen 2011) who stated that larger firms had better internal control and chances to reduce involvement in financial misstatements. The larger firms tend to provide a greater variety of information in their interim financial reports, analyst forecasts, industry and management forecast and litigation.

\section{Tax Rate}

As mentioned earlier, the tax evasion model was pioneered by (Liu \& Switzer 2013) their results indicated that tax rates have a positive relationship with tax evasion, but it depended on risk aversion assumptions and the punishment for evading. According to the research done by (Mathuva 2013) it indicated that the high margins of the tax rates may promote tax evasion because of huge gains to be made from withholding income from the tax collector. Similar findings were suggested by (Sundvik 2017) which confirmed the same result and found that the tax rate has a positive relationship with the evasion of tax. According to (Rashid et al. 2016) in Malaysia, the Royal Malaysian Customs Department (RMCD) has been entrusted by the Ministry of Finance to administer and manage all concerning GST. Therefore, RMCD is responsible for ensuring the implementation of the GST as a new tax 
system that can be achieved successfully to increase the country's revenue and also reduce the occurrence of tax evasion.

However, (Russo 2013) reported that were some circumstances where the negative correlation between tax rate and tax evasion was detected. On the other hand, (Amirah et al. 2017) found that tax rate have an unclear effect, as it depended on taxpayers risk preference. It may explain that high tax rate would influence the decision of taxpayers. These findings were consistent with the following studies: (Jegers 2013) in their analysis of taxpayer compliance; as well as (Amir et al. 2013) in their analysis of imports and exports in Hong Kong and China. The tax rate is one of the factors of the tax system structure that influenced the behavior of tax compliance. According to the deterrence theory, tax rates increased would increase the tax compliance. However, (Suwardi 2013) found that the effects of the tax rate on tax compliance would be to include the income and the substitution effects, which they argued that a higher tax rate would reduce the after-tax revenue and increase the compliance, assuming a decrease in risk aversion. Therefore, a higher tax rate would also make acts of noncompliance more profitable and referred to as the substitution effect. It could then be concluded that the net change in tax compliance behavior due to the effect of tax rate was ambiguous.

\section{Auditor's Working Experience}

John et al, (2013) explored the relationship between internal audit (focusing on audit experience and accounting qualification) and firm performance (ROA) in Malaysia. It involved 60 companies that were listed in the Malaysia Bursa in 2003. This study found a significant relationship between the experience of internal audit quality and firm performance. With the equivalent qualification and experience in auditing, it enhances the ability of an internal auditor to evaluate the risk of fraud. (Higgins 2012) found that internal auditors in the public sector do not have enough experience in auditing because some of them are often transferred to another department. The research findings of (Syahida et al. n.d.) also revealed that internal audit staff rotation will enhance and contribute to effective internal audit. This assertion supports the submissions of (Bell \& Thomas 2013). Based on both studies of internal auditors, they found that internal auditors in a situation with operating personnel familiarity were less objective when faced with an audit conflict than those auditors in the situation of little familiarity.

Then, (Taylor \& Richardson 2014) made an attempt to explore Singapore corporate management about their perception regarding the role and internal audit effectiveness. To get better results and idea, the researcher used interviews method and select managers based on ranking, experience, and decision-making autonomy. The result has shown that Singaporean senior and junior level managers perceived internal auditors behave as 'business partner'. Conversely, middle-level managers recognized internal auditors behave as 'watchdog'. This misconception can explain why (Adegoke et al. 2014) found corporate managers are less supported the implementation of recommendation provided by internal auditors. To increase internal audit effectiveness, cooperative and participative relationships are essential for internal auditors and management (Skouloudis et al. 2014).

Besides, (Onuonga 2014) found out that internal audit less effective because of independence threats, the absence of an audit planning, budget constraint, audit staff shortage and inadequate support and response from management (Rashid 2011). While (Tsipouridou \& Spathis 2012) discovered that internal audit in the private sector is more effective when audit staff have the professional membership, implement control and risk self- 
assessment to internal audit, and effective audit committee in the organization. Both studies agreed that internal audit competency contribute substantial impact.

\section{RESEARCH METHODOLOGY}

Performing consistently Mature way of speaking A clinical work was conducted. 2 groups of students Listening well from Malaysian primary school were created. 1 group Dealing with new things in life consists of normal students and the other group consists children with learning disabilities also can be primary school, not from special needs class or special characterized according to the year of schooling. During school. They were accessed with teaching skills, preschool, those children which demonstrate specific parenting skills and food supplement and the results developmental deficits or delays which have the obtained were compared before the clinical work started possibility to be the learning disabled. Preschool years and after the clinical work completed. 6 hypotheses tested represent a critical period of growth and any signs of and they are listed as follows:-

deficits must be intervened and prevented by parents, teachers and professionals .

The preschooler (4 to 6)

$\mathrm{H}$ : Scores of Malay language tests and Mathematics test years old) with a history of birth complications and do not have significant different between group who were genetic or environmental conditions, have the probability chosen for private class and not chosen for. to be among the learning disabled children. Preschoolers

with the following features need to be taken seriously,

$\mathrm{H}$ : Scores of Malay language tests and Mathematics test especially by parents, teachers and professional : have significant different between group who were Lack of symbolic play behavior Limited receptive vocabulary

$\mathrm{H}$ : Scores of Malay language tests and Mathematics test Difficulty understanding simple directions do not have significant different between group who were Reduced intelligibility chosen for parenting advice and not chosen for and Slow speed for naming objects and colors Scores of Malay language tests. Limited phonological awareness

Difficulty coloring, copying and drawing

$\mathrm{H}$ : Scores of Malay language tests and Mathematics test Distractibility have significant different between group who were

Hyperactivity chosen for parenting advice and not chosen for and Constant repetition of an idea Scores of Malay language tests.

Learning disabled children differ from non-learning

$\mathrm{H}$ : Scores of Malay language tests and Mathematics test disabled in term of way of learning, communicating and do not have significant different between group who were

socializing, due to the different treatment they get chosen for food supplement and not chosen for. because of different structure of their brain. The brains' structures among learning disabled children also differ,

$\mathrm{H}$ : Scores of Malay language tests and Mathematics test together with the learning disabilities they had been do not have significant different between group who were

diagnosed with (Nik Mohd Norfadzilah Nik Mohd Rashid, Saputri, Abdullah, et al. 2017). With the great and advances chosen for food supplement and not chosen for. researches on learning disabilities, there are now lots of treatment for learning disabled children. 
Tax non-compliance behaviour. Tax non-compliance was measured both in terms of four individual components and also through its overall value. Table 2 presents the level of tax non-compliance by the four components.

Table 2: Tax compliance/non-compliance behaviour, by type

\begin{tabular}{|c|c|c|c|c|}
\hline \multirow[t]{2}{*}{ Tax situation } & \multicolumn{2}{|c|}{$\begin{array}{l}\text { Complianc } \\
\text { e }\end{array}$} & \multicolumn{2}{|c|}{$\begin{array}{l}\text { Non- } \\
\text { complian } \\
\text { ce }\end{array}$} \\
\hline & $\mathrm{N}$ & $\%$ & $\mathrm{~N}$ & $\%$ \\
\hline Income reporting & 175 & 53 & $\begin{array}{l}15 \\
5\end{array}$ & 47 \\
\hline $\begin{array}{l}\text { Claiming } \\
\text { deductions }\end{array}$ & 175 & 53 & $\begin{array}{l}15 \\
5\end{array}$ & 47 \\
\hline Filing tax return & 108 & 33 & $\begin{array}{l}22 \\
2\end{array}$ & 67 \\
\hline $\begin{array}{l}\text { Timing of } \\
\text { payment }\end{array}$ & 108 & 33 & $\begin{array}{l}22 \\
2\end{array}$ & 67 \\
\hline
\end{tabular}

Table 2 discloses that $53 \%$ of the respondents were complying with reporting their taxable income and in claiming the correct amount of deduction, while the remaining $47 \%$ of SMEs were not complying.

This research will be based on the secondary data obtained from the RMCD Annual Report. The data was extracted from completed tax audit cases of twelve major industries, from the period of 2012 to 2014. The information of the data is stipulated under Sales Tax Act 1972, Services Tax Act 1975, Customs Act 1967, Excise Duty Act 1976 and Goods and Services Tax 2014. Questionnaires were distributed to RMCD auditors to solicit their perception on the factors contributed towards audit detection performance. The study covered the Compliance Division completed cases with no collection and resolved cases with specific collection reports with different auditors involved. Data for sampling purpose has taken into consideration on the availability of information on both the company's and auditor's profiling. From Table 1 below, the total population of completed audit cases throughout Malaysia were 7,920. From that number, cases resolved with the amount of collection were 2,678 cases. From the total number of cases, the number of cases resolved were 2,678 cases, with the median amount of per case collection was RM14,351.

Hence, this median amount of RM14,351 was used as benchmarking for sample selection which was expected to give bigger impact on audit detection cases (Ravisankar et al. 2011). Above the stated median, there were 1,175 cases. In view of the auditor's profiling for one highest collection to one auditor for the three years, the data were for 669 cases. Finally, the auditor's profiling has reduced the sampling to 461 . 
Table 1: Data Collection for Sample Selection Process for the year 2012 to 2014

\begin{tabular}{ll}
\hline & Firms \\
\hline Cases audited resolved by RMCD in 2012 to 2014 & 7,920 \\
Less : Non BOD Audit Cases resolved & $\underline{(5,222)}$ \\
\hline Tax Audit Cases Resolved with BOD & 2,698 \\
Less : Tax Cases Less Than Median 2012-2014 & $\underline{(1,523)}$ \\
Tax Audit Cases After Median & 1175 \\
Less : Tax Cases Without Auditor's Profile & $\underline{(103)}$ \\
Tax Audit Cases With Auditor's Profile & 1072 \\
Less : 1 Audit Cases with collection 1 Auditor & $\underline{403}$ \\
Tax Audit Cases with highest collection per 1 auditor & $\underline{669}$ \\
Less: Without Auditor's Profile & $\underline{\mathbf{2 0 8}}$ \\
Final Sample N & $\underline{461}$ \\
\hline
\end{tabular}

The data used for the investigation period was covered from 2012 until to 2014. A collection of the data started on 3rd September 2015 and completed on 19th October 2015. As mentioned, concerning the RMCD Annual Report, about 2,949 cases in 2012, 2374 cases in 2013 and 2597 cases in 2014 were identified to have been completed by auditors. The underpaid tax cases resolved was 785 in 2012, 921 in 2013 and 992 in 2014. The total number of cases collected was 461 as shown in Table 1 above. The following Table 2 provides a summary of the variables used for this study.

Table 2: Variables Extracted from RMCD Compliance Division Tax Audit Report

\begin{tabular}{lll}
\hline No & Variables & Abbreviation \\
\hline 1 & Audit Detection Performance & AUD_PERF \\
2 & Penalties Rate & PENALTY \\
3 & Level of Threshold & THRESHOLD \\
4 & Size of Company & CO_SIZE \\
6 & Tax Rates & TAX_RATE \\
9 & Auditor's Working Experience & AUD_EXP \\
\hline
\end{tabular}

\section{Measurement of the Variables}

The risk of probability for detection applies to all businesses regardless of their revenue utility purposes. It means that if one taxpayer decides to evade tax, then all taxpayers should do the same (Rashid et al. 2014b; Darwish, 2015). The dependent variable for this study was audit detection performance with data obtained from tax audit reports on completed case and the tax collection. Therefore, in this study, the measurement of performance to detection is the auditor's Key Performance Indicator (KPI) on the completed cases based on the difference between the actual tax collection and non-declaration of tax. Compliance Division has set the annual target of RM300 million and 48 cases per auditor. Non declaration was based on the audit findings of the company while actual tax obligation was calculated based on the actual tax finding that was discovered when the tax audit was performed. The measurement of dependent variables, denoted as AUD_PERF, was the number of completed case, the amount of actual tax obligation discovered and the number of completed case without collection. The independent variables for this study were penalty rate, level of threshold, size of the company, tax rates and auditor's working experience. The summary of the measurement for 
the variables are presented in Table 3 below. The model representing the dependent and independent variables are as follows:

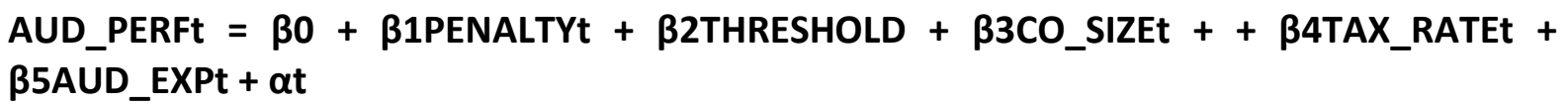

Table 3: Measurement of Variables

\begin{tabular}{|c|c|}
\hline Variables & Measurement \\
\hline AUD_PERFt & $\begin{array}{l}\text { Dependent variable; measured as the amount of evaded tax from audit } \\
\text { detection. Evaded tax is the difference between the taxable income } \\
\text { calculated by the audit and the amount not paid }\end{array}$ \\
\hline$\beta_{1}$ PENALTY $_{t}$ & Penalty amount of evaded tax \\
\hline$\beta_{2}$ THRESHOLD $_{t}$ & $\begin{array}{l}\text { Categories of threshold; No Threshold = 1; Threshold RM100,000 and } \\
\text { above = 2; Threshold RM150,000 and above = 3; Threshold RM300,000 } \\
\text { and above = 4; Threshold RM3,000,000 and above = 5. }\end{array}$ \\
\hline$\beta_{3} \mathrm{CO}_{-} \mathrm{SIZE}_{\mathrm{t}}$ & Size of company; measured from TAXABLE SALES \\
\hline $\mathrm{B}_{4} \mathrm{TAX} \_$RATE $\mathrm{t}$ & $\begin{array}{l}\text { Tariff of tax rates :Sales Tax } 10 \text { per cent, Services Tax } 6 \text { per cent; Import } \\
\text { duty } 30 \text { per cent and Excise } 120 \text { per cent }\end{array}$ \\
\hline $\mathrm{B}_{5} A U D_{-} \mathrm{EXP}_{\mathrm{t}}$ & $\begin{array}{l}\text { Auditor with sufficient experience, qualification according to years' of } \\
\text { working tenure in RMCD }\end{array}$ \\
\hline
\end{tabular}

\section{FINDINGS}

\section{Descriptive Statistics}

The descriptive statistics for several of the variables tested for each analysis is illustrated in Table 4. The descriptive statistics comprises of mean, minimum, maximum and standard deviation value. From the analysis, it shows that the mean collection from audit detection is RM 655,089 with a minimum collection of RM 11,065 and maximum of RM 56,343,291. The Key Performance Indicator (KPI) set by compliance division is RM 300 million annually. Hence, the mean shows that the result is far-off from the KPI to be achieved. The standard deviation for the audit tax detection is RM 3,120,125 of the tax evaded.

Table 4: Descriptive Statistics

\begin{tabular}{lllll}
\hline Variables & Minimum & Maximum & Mean & Std. Deviation \\
\hline Audit detection performance (RM) & $11,065.47$ & $56,343,291.39$ & $655,089.62$ & $3,120,125.75$ \\
Penalty rate (RM) & 0.00 & $7,570,932.08$ & $177,187.93$ & $690,808.54$ \\
Level of Threshold (RM) & 0 & $3,000,000$ & $267,570.50$ & $711,936.55$ \\
Size of Company (RM) & $46,585.27$ & $494,616,008.30$ & $5,003,635.45$ & $25,373,291.20$ \\
Tax Rate (RM) & 6 & 120 & 8.82 & 8.69 \\
Auditor's Working Experience (Years) & 0 & 34 & 6.07 & 5.39 \\
\hline
\end{tabular}

Based on the analysis, the maximum value of the penalty rate is $\mathrm{RM} 7,570,932.08$. The mean value is RM $177,187.93$ whilst the standard deviation is RM $690,808.54$. The maximum level of threshold is RM 3,000,000 and with a mean of RM 267,570.50. The standard deviation for the threshold is RM 711,963.55. Based on the analysis too, the minimum size of the company is RM 46,585.27 whilst the maximum size is RM 494,616,008.30. The mean size of the company is RM 5,003,635.45 with the standard deviation of RM 25,373,291.20. The minimum 
tax rate is RM 6 and the maximum is RM120. The mean tax rate is RM 8.82 with a standard deviation of RM 8.69. Finally based on the analysis, the maximum auditor's working experience is 34 years. The mean is 6 years and the standard deviation of 5 years.

\section{Normality Test}

The analysis to determine the relationship involves the use of test of significant correlation and regression. The appropriate statistical tools for this depend on the normality or nonnormality of observation values. A normality test was carried out using the Skewness and Kurtosis value on audit detection performance, penalty rate, level of threshold, size of company, tax rate and auditor's working experience. The summary statistics are presented in Table 5.

Table 5: Summary Statistics of Skewness and Kurtosis: Test of Normality

\begin{tabular}{|l|l|l|}
\hline Variable & $\begin{array}{l}\text { Skewness- } \\
\text { value }\end{array}$ & $\begin{array}{l}\text { Kurtosis } \\
\text { value }\end{array}$ \\
\hline $\begin{array}{l}\text { Audit detection } \\
\text { performance }\end{array}$ & 13.389 & 21.028 \\
\hline Penalty rate & 10.984 & 13.617 \\
\hline $\begin{array}{l}\text { Level of } \\
\text { Threshold }\end{array}$ & 3.564 & 10.911 \\
\hline Size of Company & 15.460 & 27.767 \\
\hline Tax Rate & 4.499 & 29.369 \\
\hline $\begin{array}{l}\text { Auditor's } \\
\text { Working } \\
\text { Experience }\end{array}$ & 2.904 & 3.806 \\
\hline
\end{tabular}

It can be seen that the skewness and kurtosis value for all the variables are beyond the range -2 to 2 . This means that the mean scores of audit detection performance, penalty rate, level of threshold, size of company, tax rate and auditor's working experience are not normally distributed. Following this conclusion, the study uses the non parametric statistical tool in the following analysis.

\section{Relationship between Variables}

Correlation analyses were carried out to determine the relationships, if any, between variables of audit detection performance, penalty rates, levels of threshold, size of the company, tax rates and auditor's working experience. As the variable values were found not to be normally distributed, the analyses were carried out using Spearman Coefficient Correlation, a nonparametric correlation tool. The summary statistics of the correlation analyses are presented in Tables $6-10$.

\section{Relationship between Audit Detection Performance and Penalty Rates}

Table 6 shows that audit detection performance is positively and highly correlated with penalty rates $(r=0.917 ; p<0.01)$. That is, to a big extent, an increase of audit detection performance is associated with an increase in penalty rates, and vice versa. 
Table 6: Summary Statistics of Correlation Analysis between Audit Detection Performance and Penalties

\begin{tabular}{|l|l|l|}
\hline \multirow{2}{*}{ Variable } & \multicolumn{1}{|l|}{$\begin{array}{l}\text { Audit Detection } \\
\text { Performance }\end{array}$} \\
\cline { 2 - 3 } & $\begin{array}{l}\text { Spearman } \\
\text { Coefficient } \\
\text { of } \\
\text { Correlation } \\
(\mathrm{r})\end{array}$ & \\
\hline Penalty rates & 0.917 & $0.00^{* *}$ \\
\hline
\end{tabular}

** Significant at 0.01

\section{Relationship between Audit Detection Performance and Level of Threshold}

Table 7: Summary Statistics of Correlation Analysis between Audit Detection Performance and Level of Threshold

\begin{tabular}{|l|l|l|}
\hline \multirow{2}{*}{ Variable } & \multicolumn{2}{|l|}{ Audit Detection Performance } \\
\cline { 2 - 3 } & $\begin{array}{l}\text { Spearman Coefficient } \\
\text { of Correlation }(r)\end{array}$ & $p$-value \\
\hline Level of threshold & 0.076 & 0.105 \\
\hline
\end{tabular}

The result shows that there is no significant correlation between audit detection performance and level of threshold ( $p>0.05$ ). That is, on average, there is no relationship between audit detection performance and level of threshold.

\section{Relationship between Audit Detection Performance and Size of Company}

Table 8: Summary Statistics of Correlation Analysis between Audit Detection Performance and Size of Company

\begin{tabular}{|l|l|l|}
\hline \multirow{2}{*}{ Variable } & \multicolumn{2}{|l|}{ Audit Detection Performance } \\
\cline { 2 - 3 } & $\begin{array}{l}\text { Spearman Coefficient } \\
\text { of Correlation }(r)\end{array}$ & $p$-value \\
\hline Size of company & 0.971 & $0.000^{* *}$ \\
\hline
\end{tabular}

* * Significant at 0.01

The result shows that audit detection performance and size of company are positively and highly correlated $(r=0.971 ; p<0.01)$. That is, on the average, audit detection performance which has a higher value also has a higher value of the size of company, and vice versa.

\section{Relationship between Audit Detection Performance and Tax Rates}

Table 9: Summary Statistics of Correlation Analysis between Audit Detection Performance and Tax Rates

\begin{tabular}{|l|l|l|}
\hline \multirow{2}{*}{ Variable } & \multicolumn{2}{|l|}{ Audit Detection Performance } \\
\cline { 2 - 3 } & $\begin{array}{l}\text { Spearman Coefficient } \\
\text { of Correlation }(r)\end{array}$ & $p$-value \\
\hline Tax rates & 0.143 & $0.002^{* *}$ \\
\hline
\end{tabular}

* * Significant at 0.01 
Table 9 shows that audit detection performance is positively but lowly correlated with tax rate $(r=0.143 ; p<0.01)$. That is, to low extent, an increase in audit detection performance is associated with an increase in tax rates, and vice versa.

\section{Relationship between Audit Detection Performance and Auditor's Working Experience}

Table 10: Summary Statistics of Correlation Analysis between Audit Detection Performance and Auditor's Working Experience

\begin{tabular}{|l|l|l|}
\hline \multirow{2}{*}{ Variable } & \multicolumn{2}{|l|}{ Audit Detection Performance } \\
\cline { 2 - 3 } & $\begin{array}{l}\text { Spearman Coefficient } \\
\text { of Correlation }(r)\end{array}$ & $p$-value \\
\hline Auditor's working experience & -0.013 & 0.787 \\
\hline
\end{tabular}

The result shows that there is no significant correlation between audit detection performance and auditor's working experience $(p>0.05)$. That is, on average, there is no relationship between audit detection performance and auditor's working experience.

\section{Regression Analysis}

As regression analysis requires that the data be normally distributed, the observation values were initially converted to its natural logarithmic equivalents and then subjected again to the Skewness and Kurtosis Test of normality. The summary statistics are presented in Table 11. Table 11: Summary Statistics of Skewness and Kurtosis: Test of Normality

\begin{tabular}{|l|l|l|}
\hline Variable & Skewness-value & Kurtosis value \\
\hline LN Audit detection performance (RM) & 0.770 & 0.266 \\
\hline LN Penalty rate (RM) & 0.710 & 0.152 \\
\hline LN Level of Threshold (RM) & 0.564 & 1.911 \\
\hline LN Size of Company (RM) & 0.653 & 0.042 \\
\hline LN Tax Rate (RM) & 0.638 & 1.631 \\
\hline LN Auditor's Working Experience (Years) & 0.329 & -0.197 \\
\hline
\end{tabular}

It can be seen that the Skewness and Kurtosis values for LN audit detection performance, LN penalty rate, LN level of threshold, LN size of company, LN tax rate and LN auditor's working experience are in the range -2 to 2 . That is, the observation values of audit detection performance, penalty rate, level of threshold, size of company, tax rate and auditor's working experience in its natural logarithmic equivalents are now normally distributed, hence satisfying the assumption of regression analysis.

\section{Factors Affecting Audit Detection Performance}

A regression equation was estimated with $L N$ audit detection performance score as the dependent variable, and LN penalty rates, LN level of threshold, LN size of company, LN tax rates and $L N$ auditor's working experience as the independent variables. Table 12 presents the summary statistics of the estimated regression equation. 
Table 12: Estimated Regression Equation

\begin{tabular}{|l|l|l|l|}
\hline Variable & Coefficient & t-value & p-value \\
\hline 1. LN Penalty rates & 0.225 & 19.665 & $0.000^{* *}$ \\
\hline $\begin{array}{l}\text { 2. LN Level of } \\
\text { threshold }\end{array}$ & 0.002 & 0.399 & 0.690 \\
\hline 3. LN Size of company & 0.774 & 68.293 & $0.000^{* *}$ \\
\hline 4. LN Tax rates & 0.764 & 40.511 & $0.000^{* *}$ \\
\hline $\begin{array}{l}\text { 5. LN Auditor's } \\
\text { working experience }\end{array}$ & -0.003 & -0.525 & 0.600 \\
\hline $\mathrm{F}$ & 285.79 & & $0.000^{* *}$ \\
\hline $\mathrm{R}^{2}$ & 0.668 & & \\
\hline
\end{tabular}

** Significant at 0.01

The regression equation is statistically significant at $0.01(p<0.01)$, implying that there is an association between audit detection performance and any or all of the independent variables. However, the R-square value being 0.668 means that the five independent variables as a whole account for 67 per cent of the variation in the dependent variable (audit detection performance).

Hence, the effect of penalty rates, level of threshold, size of company, tax rates and auditor's working experience as a whole on audit detection performance is moderately high.

Looking at the individual regression coefficient, one finds that only the coefficient of LN penalty rates, LN size of company and LN tax rate are statistically significant at 0.01 $(p<0.01)$, whereas those of $L N$ level of threshold and LN auditor's working experience are not. The coefficient of LN penalty rate (0.225), LN size of company (0.774) and LN tax rate (0.764) means that an increase in penalty rates, size of company and tax rate, increases the audit detection performance, whilst changes in the other two variables have no impact on audit detection performance.

\section{CONCLUSION}

GST will be based on Self-assessment method. In order to ensure that it can pave the way to the need for both parties; the law enforcement and taxpayers need to be able to sit down together to discuss and find solutions for the needs of establishing multilateral Assisted Compliance Program for the knowledge sharing. In order to uphold the tax compliance, the necessary steps needs to be installs such as the awareness and handholding program since compliance is a subjective matter. This situation requires assistance from law enforcement authorities. It is suggested that the Assisted Compliance Program should be introduced and to be expanded to all states.

RMCD should consider determining the organisational and structural issues, secure resources, recruitment and staff training. In terms of operational, it is essential to formulate GST policy and legislations, design operating process and procedure, develop the computer system, prepare guides and instructions and design new forms of audit reporting. For external consideration, RMCD should consult with the private sector, educate taxpayer and the public. GST introduction also needs the RMCD to consider reviewing the process \& procedures, policy, publicity, computer system, staffing and training, standing instructions and guides.

Effective risk management is crucial in modern customs operations and makes it possible to achieve an appropriate balance between business facilitation and regulatory control. By means of the importance of risk management system in Customs administration, the 
development of risk profiles can be established from the analysed data as well. From this research, the clear understanding of the nature of the risks of businesses would provide methods of mitigating those risks. The findings could assist RMCD in optimizing its resources whether in the physical inspection or selectivity programmes in its auditing routine.

Therefore, the Compliance Division of RMCD should give emphasis to use these predictors to make their service delivery effective, efficient, economical and value for money throughout their offices. Moreover, the competency of auditor's staff was the major factor of audit function effectiveness in RMCD, rather than management support and independence factor. With regards to the competency, it is the highest contributor towards the effectiveness of audit detection performance in RMCD. The needs to enhance this competency in terms of knowledge and skills have to be enriched in each auditor. This study finding is in line with the previous research done by (Abdullah \& Morley 2014) which indicated that competency has direct positive relationship with audit detection performance in RMCD context. Training and course on developmentas well as the exposure to new audit technique will be the mitigating measures that need to be given attention by the government to enhance the competence of audit staff.

\section{Acknowledgements}

The authors would like to convey their appreciation to the Ministry of Higher Education of Malaysia for providing the fundamental research grant to undertake this project. Appreciation also goes to the Faculty of Accountancy, Accounting Research Institute (ARI) and Institute of Research Management and Innovation (IRMI), Universiti Teknologi MARA, Malaysia for the supports in this study.

\section{References}

Abdullah, S., \& Morley, B. (2014). Environmental taxes and economic growth: Evidence from panel causality tests. Energy Economics, 42(1), pp.27-33. Available at: http://linkinghub.elsevier.com/retrieve/pii/S0140988313002752 [Accessed August 6, 2014].

Aerts, W., \& Zhang, S. (2014). Management's causal reasoning on performance and earnings management. European Management Journal, 32(5), pp.770-783. Available at: http://linkinghub.elsevier.com/retrieve/pii/S026323731300162X [Accessed June 1, 2014].

Alm, J., \& Torgler, B. (2011). Do Ethics Matter? Tax Compliance and Morality. Journal of Business Ethics, 101(4), pp.635-651. Available at:

http://www.springerlink.com/index/10.1007/s10551-011-0761-9 [Accessed March 5, 2013].

Amir, H., Asafu-Adjaye, J., \& Ducpham, T. (2013). The impact of the Indonesian income tax reform: A CGE analysis. Economic Modelling, 31, pp.492-501. Available at: http://linkinghub.elsevier.com/retrieve/pii/S0264999312004464 [Accessed August 13, 2014].

Baber, W. R., Krishnan, J., \& Zhang, Y. (2014). Investor perceptions of the earnings quality consequences of hiring an affiliated auditor. Review of Accounting Studies, 19(1), pp.69102.

Bell, T. J., \& Thomas, J. (2013). Tax benefits of leasing. Economics Letters, 120(2), pp.338-341. Available at: http://linkinghub.elsevier.com/retrieve/pii/S0165176513002425 [Accessed September 23, 2014]. 
Benmelech, E., \& Dvir, E. (2013). Does Short-Term Debt Increase Vulnerability to Crisis? Evidence from the East Asian Financial Crisis. Journal of International Economics, 89(2), pp.485-494. Available at: http://dx.doi.org/10.1016/j.jinteco.2011.12.004.

Bouraoui, T., Li, T., \& An, P. (2014). The Impact Of Adjustment In Capital Structure In Mergers \& Acquisitions On Us Acquirers' Business Performance. The Journal of Applied Business Research, 30(1), pp.27-41.

Braun, G., \& Rodriguez, Jr., R. P. (2014). Using Gray's (1988) Accounting Values to Explain Differing Levels of Implementation of IFRS. International Journal of Accounting and Financial Reporting, 4(2), p.104.

Cerqueti, R., \& Coppier, R. (2011). Economic growth, corruption and tax evasion. Economic Modelling, 28(1-2), pp.489-500. Available at: http://linkinghub.elsevier.com/retrieve/pii/S0264999310001331 [Accessed August 14, 2014].

Daniela, P., \& Attila, T. (2013). Internal Audit versus Internal Control and Coaching. Procedia Economics and Finance, 6(13), pp.694-702. Available at: http://linkinghub.elsevier.com/retrieve/pii/S2212567113001913.

Danielova, A., \& Sarkar, S. (2011). The effect of leverage on the tax-cut versus investmentsubsidy argument. Review of Financial Economics, 20(4), pp.123-129. Available at: http://linkinghub.elsevier.com/retrieve/pii/S1058330011000371 [Accessed September 28, 2014].

Darwish, S. Z. (2015). Risk and Knowledge in the Context of Organizational Risk Management. Risk, 7(15).

Dellaportas, S. (2013). Conversations with inmate accountants: Motivation, opportunity and the fraud triangle. Accounting Forum, 37(1), pp.29-39. Available at: http://linkinghub.elsevier.com/retrieve/pii/S0155998212000518 [Accessed January 9, 2015].

Hana, S., Isa, K., \& Mohdali, R. (2014). An analysis of the gap between accounting depreciation and tax capital allowance in Malaysia. Procedia - Social and Behavioral Sciences, 164(August), pp.351-357. Available at: http://dx.doi.org/10.1016/j.sbspro.2014.11.087.

Hashimzade, N., Huang, Z., \& Myles, G. D. (2010). Tax fraud by firms and optimal auditing. International Review of Law and Economics, 30(1), pp.10-17. Available at: http://linkinghub.elsevier.com/retrieve/pii/S014481880900057X [Accessed February 25, 2014].

Higgins, H. N. (2012). Learning internal controls from a fraud case at bank of China. Issues in Accounting Education, 27(4), pp.1171-1192.

Jegers, M. (2013). Do Nonprofit Organisations Manage Earnings? An Empirical Study. Voluntas, 24(4), pp.953-968.

John, M., Pokhariyal, G. P., \& Beatrice, O. (2013). The Influence of External Stakeholders and Expansion Strategies on the Relationship between Organisational Resources and Firm Corresponding Author: Mahasi John. Journal of Emerging Trends in Economics and Management Sciences, 4(5), pp.449-459.

Kenyon, T. (2008). Tax Evasion, Disclosure, and Participation in Financial Markets: Evidence from Brazilian Firms. World Development, 36(11), pp.2512-2525. Available at: http://linkinghub.elsevier.com/retrieve/pii/S0305750X08001599 [Accessed August 14, 2014].

Litt, B., Sharma, D., \& Sharma, V. (2013). Environmental initiatives and earnings management. Managerial Auditing Journal, 29(1), pp.76-106. Available at: 
http://www.emeraldinsight.com/10.1108/MAJ-05-2013-0867.

Liu, J., \& Switzer, L. N. (2013). Convertible bond issuance, risk, and firm financial policy: A new approach. International Journal of Business, 18(1), pp.1-25.

Mathuva, D. M. (2013). Determinants of Corporate Inventory Holdings: Evidence from a Developing Country. The International Journal Of Applied Economic and Finance, 7(1), pp.1-22.

Moyes, G. D., Young, R., \& Din, H. F. M. (2013). Malaysian internal and external auditor perceptions of the effectiveness of red flags for detecting fraud. International Journal of Auditing Technology, 1(1), pp.91-106.

Nicolaes, C., Risti, L., \& Tagaduan, D. (2015). Study regarding the Quality of Accounting Information under the Conditions of using Creative Accounting. Journal of Economics and Business Research, 1(1), pp.182-190.

Noor, R. M., Matsuki, N., \& Bardai, B. (2008). Corporate Effective Tax Rate : A Study on Malaysia Public Listed Companies. Malaysian Accounting Review, 7(1), pp.1-18.

Onuonga, S. M. (2014). Financial Development and Economic Growth in Kenya: An Empirical Analysis 1980-2011. International Journal of Economics and Finance, 6(7), pp.226-242. Available at: http://www.ccsenet.org/journal/index.php/ijef/article/view/35978.

Overesch, M., \& Wamser, G. (2014). Bilateral internal debt financing and tax planning of multinational firms. Review of Quantitative Finance and Accounting, 42(2), pp.191-209.

Rashid, N. M. N. N. M. (2011). Tax and Zakat Reporting of Shariah-Compliant Companies In Malaysia. University Of Techology MARA, Unpublished Thesis.

Rashid, N. M. N. N. M., Noor, R. M., \& Mastuki, N. A. (2015). SOCIAL SCIENCES \& HUMANITIES Longitudinal Study of Corporate Tax Planning : Analysis on Companies ' Tax Expense and Financial Ratios. Pertanika Journal of Social Sciences \& Humanities, 23((S)), pp.109-120.

Richardson, G., Taylor, G., \& Lanis, R. (2013). Determinants of transfer pricing aggressiveness: Empirical evidence from Australian firms. Journal of Contemporary Accounting \& Economics, 9(2), pp.136-150. Available at:

http://linkinghub.elsevier.com/retrieve/pii/S1815566913000167 [Accessed January 12, 2015].

Russo, F. F. (2013). Tax morale and tax evasion reports. Economics Letters, 121(1), pp.110114. Available at: http://linkinghub.elsevier.com/retrieve/pii/S0165176513003285 [Accessed June 1, 2014].

Saad, N. (2014). Tax Knowledge, Tax Complexity and Tax Compliance: Taxpayers' View. Procedia - Social and Behavioral Sciences, 109(1), pp.1069-1075. Available at: http://linkinghub.elsevier.com/retrieve/pii/S1877042813052294 [Accessed July 26, 2014].

Schweinberger, M. (2012). Statistical modeling of network panel data: Goodness-of-fit. British Journal of Mathematical and Statistical Psychology, 65(2), pp.263-281. Available at: http://scholar.google.com/scholar?hl=en\&btnG=Search\&q=intitle:STATISTICAL+MODEL ING+OF+NETWORK+PANEL+DATA:+GOODNESS-OF-FIT\#O.

Sundvik, D. (2017). Tax-induced fiscal year extension and earnings management. Journal of Applied Accounting Research, 18(3), pp.356-374.

Suwardi, E. (2013). Income Tax Rate and Earnings Managemen tof Firms Listed On the Indonesian Stock Exchange Suwardi. Journal of Business and Policy Research, 8(1), pp.78-89.

Taylor, G., \& Richardson, G. (2014). Incentives for corporate tax planning and reporting: Empirical evidence from Australia. Journal of Contemporary Accounting \& Economics, 
10(1), pp.1-15. Available at:

http://linkinghub.elsevier.com/retrieve/pii/S1815566913000337 [Accessed May 24, 2014].

Toolson, R. B. (2014). HIGHER TAX RATES INCREASE IMPORTANCE OF CHOOSING TAX EFFICIENT. , (March), pp.108-116.

Tsipouridou, M., \& Spathis, C. (2012). Earnings management and the role of auditors in an unusual IFRS context: The case of Greece. Journal of International Accounting, Auditing and Taxation, 21(1), pp.62-78. Available at:

http://linkinghub.elsevier.com/retrieve/pii/S1061951812000067 [Accessed November 9, 2014].

Vijayakumar, A., \& Karunaiathal, A. (2014). The effect of capital structure on profitability: an empirical analysis of listed firms in Ghana. International Research Journal of Business and Management, 6(5), pp.28-42.

Vladu, A. B., \& Matis, D. (2010). Corporate Governance and Creative Accounting: Two Concepts Strongly Connected? Some Intersting Insights Highlighted By Constructing the Internal History of a Literature. Annales Universitatis Apulensis Series Oeconomica, 12(1), pp.332-346.

Wang, J. L. (2013). Accounting Conservatism and Information Asymmetry: Evidence from Taiwan. International Business Research, 6(7), pp.32-44. Available at: http://www.ccsenet.org/journal/index.php/ibr/article/view/28295.

Ying, T., Wright, B., \& Huang, W. (2017). Ownership structure and tax aggressiveness of Chinese listed companies. International Journal of Accounting and Information Management, 25(3), pp.313-332.

Corresponding Author: Nadiah Abdul Hamid, Faculty of Accountancy, Universiti Teknologi MARA, 42300 Bandar Puncak Alam, Malaysia. Email : nadiah201@salam.uitm.edu.my 